\title{
The Pharmacokinetics of Penicillamine in a Female Mongrel Dog
}

\author{
Richard F. Bergstrom, ${ }^{1,3,4}$ Donald R. Kay, ${ }^{2,5}$ and John G. Wagner ${ }^{1,6}$
}

Received August 22, 1980-Final February 6, 1981

The pharmacokinetic parameters of D-penicillamine were investigated by administering four intravenous bolus doses, four oral doses, and six constant rate intravenous infusions to a female mongrel dog at dosages comparable to $250,500,750$, and $1000 \mathrm{mg}$ in man. The pharmacokinetics of D-penicillamine demonstrated nonlinearity in the dog. There was more than proportional increase in the area under the whole blood concentration curve for an increase in the bolus intravenous dose. The steady state whole blood, plasma, and packed cell levels of penicillamine were increased more than proportionately for an increase in the intravenous infusion rate. Total body clearance of penicillamine was decreased by increasing the dose or the infusion rate of penicillamine. Correspondingly, the estimated half-life of unchanged penicillamine in the whole blood was decreased for increased intravenous bolus doses. The renal clearance of penicillamine was nonlinear, decreasing with time during the bolus experiments and increasing at higher infusion rates. The nonrenal clearance was decreased at higher infusion rates, suggesting that a saturable nonrenal elimination process exists for penicillamine in the dog. The nonlinearities that were observed in the dog, if also present in man, may be responsible in part for the dose related side effects reported clinically for penicillamine.

KEY WORDS: D-penicillamine pharmacokinetics; D-penicillamine whole blood and plasma concentrations; rheumatoid arthritis; iv bolus, infusion, and oral administration of penicillamine; bioavailability of penicillamine; female mongrel dog.

This research was supported in part by a National Institutes of Health Grant (AM-20557-02$51)$.

College of Pharmacy and Upjohn Center for Clinical Pharmacology, The University of Michigan, Ann Arbor, Michigan 48109.

${ }^{2}$ Rackham Arthritis Research Unit and Upjohn Center for Clinical Pharmacology, The University of Michigan, Ann Arbor, Michigan 48109.

${ }^{3}$ 1980-1981 American Foundation for Pharmaceutical Education Manufacturing and Industrial Pharmacy Fellow.

${ }^{4}$ Present address: Lilly Research Laboratories, Lilly Laboratory for Clinical Research, Wishard Memorial Hospital, Indianapolis, Indiana 46202.

${ }^{5}$ Present address: Division of Immunology and Rheumatology, Department of Medicine, University of Missouri, Columbia, Missouri.

${ }^{6}$ Address all correspondence to Dr. J. G. Wagner. 


\section{INTRODUCTION}

Penicillamine has been used therapeutically since 1954 when Walshe first introduced the agent for the treatment of Wilson's disease (1). The name, penicillamine, was coined by Abrams et al. (2) when the amino acid was first isolated as a degradation product of penicillin. More recent studies of its therapeutic activities $(3,4)$ have shown penicillamine to be effective in the treatment of rheumatoid arthritis.

The latter application has prompted a greater usage of this drug and concomitantly an increased interest in research on it. A major stimulus for this increased usage and research is the high incidence and debilitating nature of rheumatoid arthritis. However, throughout the several decades of penicillamine therapy, pharmacokinetic studies have never been adequately carried out, primarily due to the lack of a specific and sensitive assay for the compound. Due to penicillamine's chemical similarity to a number of endogenous compounds, a specific assay is essential to accurately define its pharmacokinetics. Many very sensitive analytical methodologies which have been developed for penicillamine, such as colorimetric (5), gas chromatographic $(6)$, and radioimmunoassay $(7,8)$, are not useful for pharmacokinetic studies as a result of the possibility of interference from endogeneous compounds or penicillamine's metabolites or as a result of other limitations of these analytical methodologies.

To avoid these analytical assay problems, previous penicillamine pharmacokinetic studies have been done in animals (9-14) and man (15-17) using radiolabeled penicillamine. These studies are inappropriate to describe pharmacokinetics of unchanged penicillamine, however, as the results represent both the parent compound, penicillamine, and penicillamine's metabolites or metabonates: penicillamine disulfide, penicillamine cysteine disulfide, and S-methyl-penicillamine (18).

To further complicate the study of penicillamine pharmacokinetics, in vitro studies in our laboratory have shown a rapid loss of penicillamine in whole blood, plasma, and albumin solutions (19). Thus to accurately reflect the concentration of the unchanged drug in biological samples, the analytical samples must be processed quickly to avoid a significant change in the penicillamine concentration. The studies reported in this paper used methods reported previously (19) to stabilize the reduced penicillamine present in the samples.

The recent development of a high performance liquid chromatographic (HPLC) method for the determination of penicillamine $(20,21)$ has provided an assay method with the specificity and sensitivity necessary to conduct pharmacokinetic studies of unchanged penicillamine. We have modified this HPLC method and adapted it for use in our laboratory (22). In this paper, we present the results of intravenous bolus, intravenous infusion, 
and oral administration pharmacokinetic studies of penicillamine in a female mongrel dog.

\section{EXPERIMENTAL}

\section{Materials and Methods}

The pharmacokinetics of penicillamine were studied following the administration of single doses of penicillamine in a female mongrel dog (Hodgins Kennel, Howell, Mich. 48843). All of these studies were performed in a single dog to eliminate variation between animals. During the course of these studies, the dog's weight ranged from 21 to $28 \mathrm{~kg}$. The doses of penicillamine were administered on a $\mathrm{mg} / \mathrm{kg}$ basis to make the doses equivalent to $250,500,750$, and $1000 \mathrm{mg}$ of penicillamine in a $70 \mathrm{~kg}$ man. The dog's weight was accurately determined prior to each dose.

For all studies, the dog was fasted for $24 \mathrm{hr}$ prior to the dose and during the experimental period. The dog was conscious throughout the entire experimental procedure, and no anesthetic agents or tranquilizing drugs were administered at any time. The dog was restrained by means of a headlock sling apparatus.

An indwelling foley urinary cannula inserted prior to each study was used to collect the urine specimens. An intravenous cannula (8 in., 19 gauge), placed into the cephalic vein of the forepaw, was used to collect blood samples. From 2 to $3 \mathrm{ml}$ of whole blood was withdrawn from the cannula and discarded prior to obtaining the actual 3-5 $\mathrm{ml}$ blood sample for analysis. On occasion, the cannula was flushed with sterile $0.9 \%$ sodium chloride between samples. Approximately $500 \mathrm{ml}$ of water was given through a gastric tube $30 \mathrm{~min}$ prior to the iv bolus and oral doses to promote adequate urine flow throughout the experimental period. During the infusion studies, $100 \mathrm{ml}$ of water was given through a gastric tube at the start of each new infusion.

The dosage form for all of these studies except the one dose administered in capsule form was an extemporaneously compounded solution of penicillamine. The solution of penicillamine $(50 \mathrm{mg} / \mathrm{ml})$ was prepared in advance of all studies by dissolving D-penicillamine $(99 \%+$ purity, Aldrich Chemical Co., Milwaukee, Wis. 53233) in an ethylene diamine tetracetic acid disodium salt (EDTA) solution (1 g/liter). The solution was sterile filtered ( $25 \mathrm{~mm} 0.22 \mu \mathrm{m}$ membrane filter, Millipore Corp., Bedford, Mass. 01730) and was aseptically transferred into sterile $5 \mathrm{ml}$ glass seal ampuls purged with sterile filtered nitrogen. The ampuls were aseptically sealed and then refrigerated until used. Ampuls of penicillamine prepared as above are reported to be stable for over a year $(20,23)$. Assays of the penicillamine solution at the beginning and end of the studies confirmed 
that no significant change of penicillamine concentration had occurred during storage. The one dose administered as capsules utilized $125 \mathrm{mg}$ Cuprimine capsules (125 mg lot no. A1661, penicillamine, Merck Sharp and Dohme, West Point, Pa. 19486).

\section{Intravenous Bolus Administration}

Four doses of penicillamine $(14.3,10.7,7.1$, and $3.6 \mathrm{mg} / \mathrm{kg})$ were administered by bolus intravenous injection $(<5 \mathrm{~s})$ via an intravenous cannula ( 8 in., 19 gauge) inserted in the opposite cephalic vein to that used for the blood sample site. The dosage administration cannula was immediately flushed with 5 to $10 \mathrm{ml}$ of sterile $0.9 \%$ sodium chloride solution following the dose. A single intravenous bolus dose was administered at intervals of 2 weeks to allow sufficient time for blood volume recovery and drug washout. Blank urine and whole blood samples were obtained prior to the start of every dose of penicillamine. Then whole blood samples were obtained at $1,10,20,30,40,60,80,100,120,150,180,210,240,270$, and $300 \mathrm{~min}$ after the dose. Total void urine samples were obtained at 0 , $15,30,45,60,90,120,180,240$, and $300 \mathrm{~min}$. For all urine samples, the volume was accurately measured and recorded.

\section{Oral Administration}

Three doses of penicillamine (one 14.3 and two $10.7 \mathrm{mg} / \mathrm{kg}$ ) were administered orally in solution form via a gastric tube. From 50 to $75 \mathrm{ml}$ of water was administered immediately after the dose to flush the gastric tube. Blank whole blood and urine samples were collected prior to the dose. Then whole blood samples were obtained at $10,20,30,40,50,60$, $70,80,90,100,120,140,160,180,210,240,270,300,330$, and $360 \mathrm{~min}$ after the administration of the dose of penicillamine. Urine samples were collected on a schedule similar to that of the I.V. bolus experiments. A similar oral administration experiment was also completed using a capsule dosage form. Two capsules $(2 \times 125 \mathrm{mg}=250 \mathrm{mg}=9.9 \mathrm{mg} / \mathrm{kg})$ were administered orally, and blood and urine samples were obtained as detailed above.

\section{Intravenous Infusion Administration}

A total of six constant rate infusions $(0.21,0.41,0.82,1.3,1.7$, and $2.1 \mathrm{mg} / \mathrm{min}$ ) were administered on two separate days, two weeks apart, giving three consecutive increasing rate infusions on each day. The infusion rates (mass/time) were controlled by altering the concentration of the infusion solution $(\mathrm{mg} / \mathrm{ml})$ and maintaining a constant volume infusion rate $(\mathrm{ml} / \mathrm{min})$. For this purpose, a calibrated Harvard infusion pump (model 
975, Harvard Apparatus, Millis, Mass. 02054) was used to maintain a constant volume infusion rate of $0.139 \mathrm{ml} / \mathrm{min}$. Six solutions of penicillamine $(1.5,3.0,6.0,9.0,12.0$, and $15.0 \mathrm{mg} / \mathrm{ml})$ in EDTA $(1 \mathrm{~g} /$ liter $)$ were infused through a sterile $25 \mathrm{~mm} 0.22 \mu \mathrm{m}$ membrane filter (Millipore Corp., Bedford, Mass. 01730) via an intravenous cannula inserted into the cephalic vein opposite to the site of the blood sample cannula. The concentrations of each of the infusion solutions were checked at the time of the assay of the pharmacokinetic samples to confirm their concentration.

Each penicillamine solution was infused over a period of $4 \mathrm{hr}$ to achieve a different steady state blood level of penicillamine. Blood samples, including whole blood, plasma, and packed cell fractions, were collected at three time points approximately $20 \mathrm{~min}$ apart during the fourth hour of each infusion. Urine formed during the first $3 \mathrm{hr}$ of each infusion was collected and discarded. Then the urine excreted during the final fourth hour was collected over an accurately timed interval. The measurement of penicillamine in these urine samples allowed an accurate calculation of the renal clearance when the blood levels of penicillamine were at steady state.

\section{Sample Treatment and Assay Procedure}

The samples of whole blood, plasma, packed cells, or urine were treated immediately after collection to stabilize the amount of penicillamine present in the samples. The whole blood samples for the i.v. bolus and oral solution studies were drawn using plain $3 \mathrm{ml}$ syringes. The blood samples for the i.v. infusion studies and oral capsule study were drawn using heparinized $5 \mathrm{ml}$ syringes (approximately $50 \mu \mathrm{l}$ of $1000 \mathrm{U} / \mathrm{ml}$ heparin per $5 \mathrm{ml}$ syringe). A rapid separation of blood into plasma and packed cell components was achieved using a high speed microcentrifuge (model 5412, Brinkmann Instrument Co., Westbury, N.Y. 11590) $(15,000 \mathrm{~g}$ for $30 \mathrm{~s})$.

Whole blood and packed cell samples were diluted (1:1) and hemolyzed using an EDTA solution ( $1 \mathrm{~g} /$ liter $)$, and then the proteins were precipitated and the $\mathrm{pH}$ decreased by the addition of a metaphosphoric acid solution $(500 \mathrm{~g} /$ liter $)$ using $0.5 \mathrm{ml}$ metaphosphoric acid solution per $\mathrm{ml}$ of whole blood or packed cells. The plasma samples were stabilized by the addition of $0.2 \mathrm{ml}$ of a trichloroacetic acid solution $(20 \% \mathrm{w} / \mathrm{v})$ per $\mathrm{ml}$ of plasma, which caused a decrease in the $\mathrm{pH}$ and a precipitation of the plasma proteins. These precipitates were centrifuged, and the supernatants were decanted and immediately refrigerated or placed on ice.

The urine samples were accurately measured for totai volume. Then a suitable aliquot was diluted $(1: 5$ or $1: 10)$ using a $0.4 \mathrm{M}$ citric acid solution to decrease the $\mathrm{pH}$ and stabilize the penicillamine. The protein free supernatants from whole blood, plasma, and packed cells and the diluted urine 
samples were assayed for penicillamine using our modification (22) of the previously published electrochemical HPLC assay (20) for penicillamine.

\section{RESULTS}

\section{I.V. Bolus Administration}

The whole blood concentration time courses for the four intravenous bolus doses administered to the dog are shown in Fig. 1. This semilogarithmic plot shows the effect of the dose dependent pharmacokinetics of

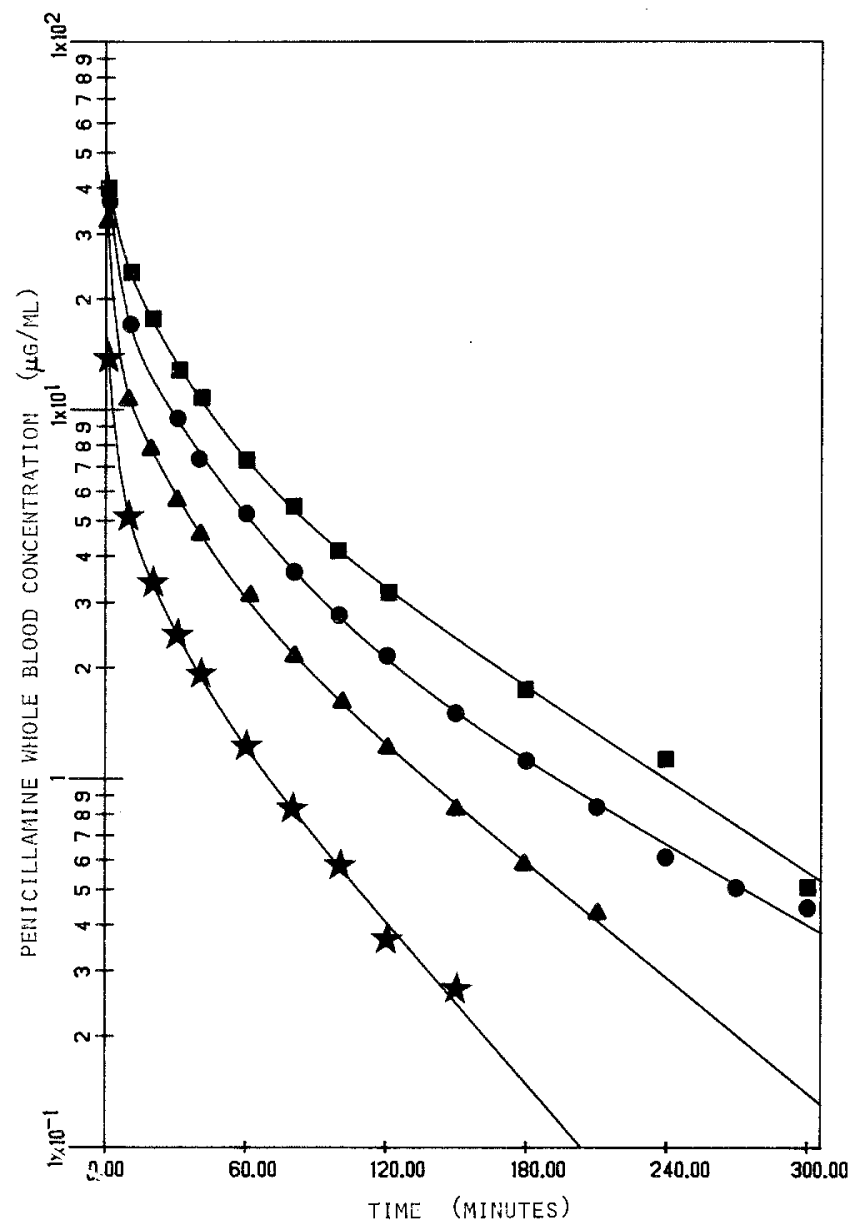

Fig. 1. Penicillamine whole blood concentration vs. time for four i.v. bolus doses of peniciliamine in a female mongrel dog. Squares, $14.3 \mathrm{mg} / \mathrm{kg}$; circles, $10.7 \mathrm{mg} / \mathrm{kg}$; triangles, $7.1 \mathrm{mg} / \mathrm{kg}$; stars, $3.6 \mathrm{mg} / \mathrm{kg}$. 
D-penicillamine in the female mongrel dog. The terminal log-linear phases for the four different doses are not parallel as is expected for a linear system, but the slope of the terminal log-linear phases are decreasing with increased dosage. This change in the slope with the dose corresponds to an increase in the half-life and a decrease in the clearance of penicillamine with an increase in the penicillamine dose.

The whole blood concentration data of these four experiments were stripped using the digital computer program CSTRIP (24) and were found to fit a triexponential function significantly better than a biexponential. Using the preliminary estimates for the triexponential fits from CSTRIP, the i.v. bolus dog data were fitted by the method of least squares to a triexponential equation using the digital computer program NONLIN (25).

Because of the excellent fits obtained with NONLIN, $\left(R^{2}\right.$ and Corr $>$ 0.999 ), the triexponential functions were used to calculate the pharmacokinetic parameters shown in Table I. The results presented in this table also demonstrate the dose dependent pharmacokinetics of penicillamine in this female mongrel dog. As the dose was increased, there was a significant decrease in the total body clearance of penicillamine and an increase in the hail-life. Also shown in Table $I$ is the percentage of the dose of penicillamine that was excreted unchanged in the urine. The urinary data also demonstrated $a$ dose dependency as the percentage of the dose excreted in the urine was increased as the dose increased.

The asymptotic values of the cumulative amount excreted for each dose were divided into the respective cumulative amounts at each time

Table I. Pharmacokinetic Parameters of Penicillamine Determined from Four i.v. Bolus Doses in a Female Mongrel Dog

\begin{tabular}{|c|c|c|c|c|c|}
\hline $\begin{array}{c}\text { Dose } \\
(\mathrm{mg} / \mathrm{kg})\end{array}$ & $\begin{array}{c}\text { Area under } \\
\text { curve }^{a} \\
(\mu \mathrm{g} * \min / \mathrm{ml})\end{array}$ & $\begin{array}{c}\text { Total } \\
\text { clearance }^{b} \\
(\mathrm{ml} / \mathrm{min})\end{array}$ & $\begin{array}{l}\text { Half-life }^{c} \\
\text { (hr) }\end{array}$ & $\begin{array}{l}\text { Elimination } \\
\text { rate constant } \\
\left(\mathrm{hr}^{-1}\right)\end{array}$ & $\begin{array}{l}\text { Amiount in } \\
\text { urine } \\
(\% \text { dose })\end{array}$ \\
\hline 3.6 & 278 & 326 & 0.69 & 1.00 & 14.6 \\
\hline 7.1 & 690 & 268 & 0.97 & 0.716 & 17.6 \\
\hline 10.7 & 1160 & 211 & 1.4 & 0.494 & 23.5 \\
\hline 14.3 & 1600 & 196 & 1.2 & 0.576 & 26.3 \\
\hline
\end{tabular}

${ }^{a}$ The area under the whole blood concentration curve from time zero to infinity is calculated by integration of the NONLIN polyexponential function fit to the observed whole blood concentration data.

${ }^{b}$ The total body clearance calculated from the ratio of the dose $(\mu \mathrm{g})$ over the whole blood AUC $(\mu \mathrm{g} * \mathrm{~min} / \mathrm{ml})$.

${ }^{c}$ The half-life determined from the smallest rate constant of the NONLIN fit of the observed whole blood concentration data.

${ }^{d}$ The elimination rate constant from the NONLIN fit.

'The cumulative amount of penicillamine found in the urine extrapolated to infinity and expressed as a percentage of the administered dose. 
point, and these ratios are plotted against time. As shown in Fig. 2, the curves are not superimposed. The order of the curves for these ratios are reversed with respect to the dose such that the largest dose gives the smallest ratios. These results confirm that the urinary excretion data for penicillamine in this dog are dose depeindent.

As shown in Fig. 3, the urinary excretion rate of penicillamine was not directly proportional to the concentration of penicillamine in the whole

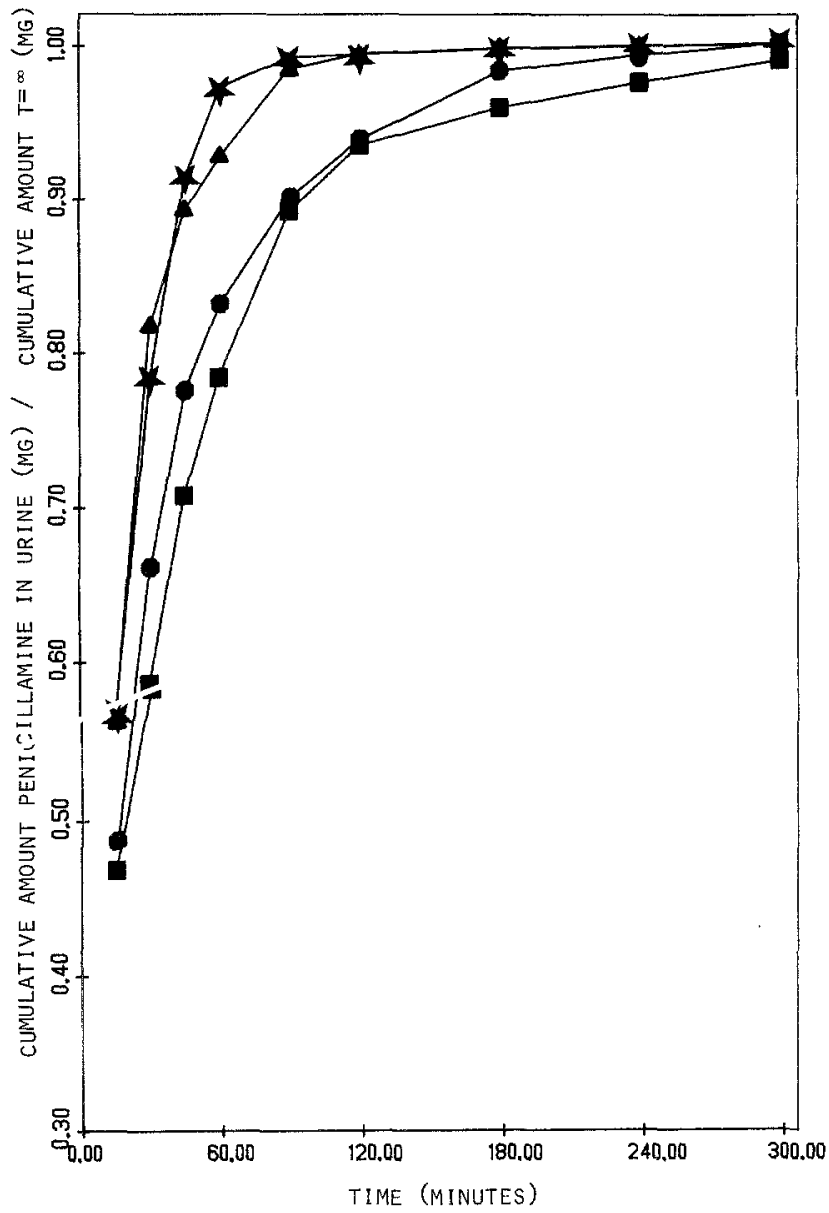

Fig. 2. Ratios of the amount of penicillamine excreted in the urine over the amount excreted to infinity vs. time for the four i.v. bolus doses of penicillamine in a female mongrel dog. Squares, $14.3 \mathrm{mg} / \mathrm{kg}$; circles, $10.7 \mathrm{mg} / \mathrm{kg}$; triangles, $7.1 \mathrm{mg} / \mathrm{kg}$; stars, $3.6 \mathrm{mg} / \mathrm{kg}$. 


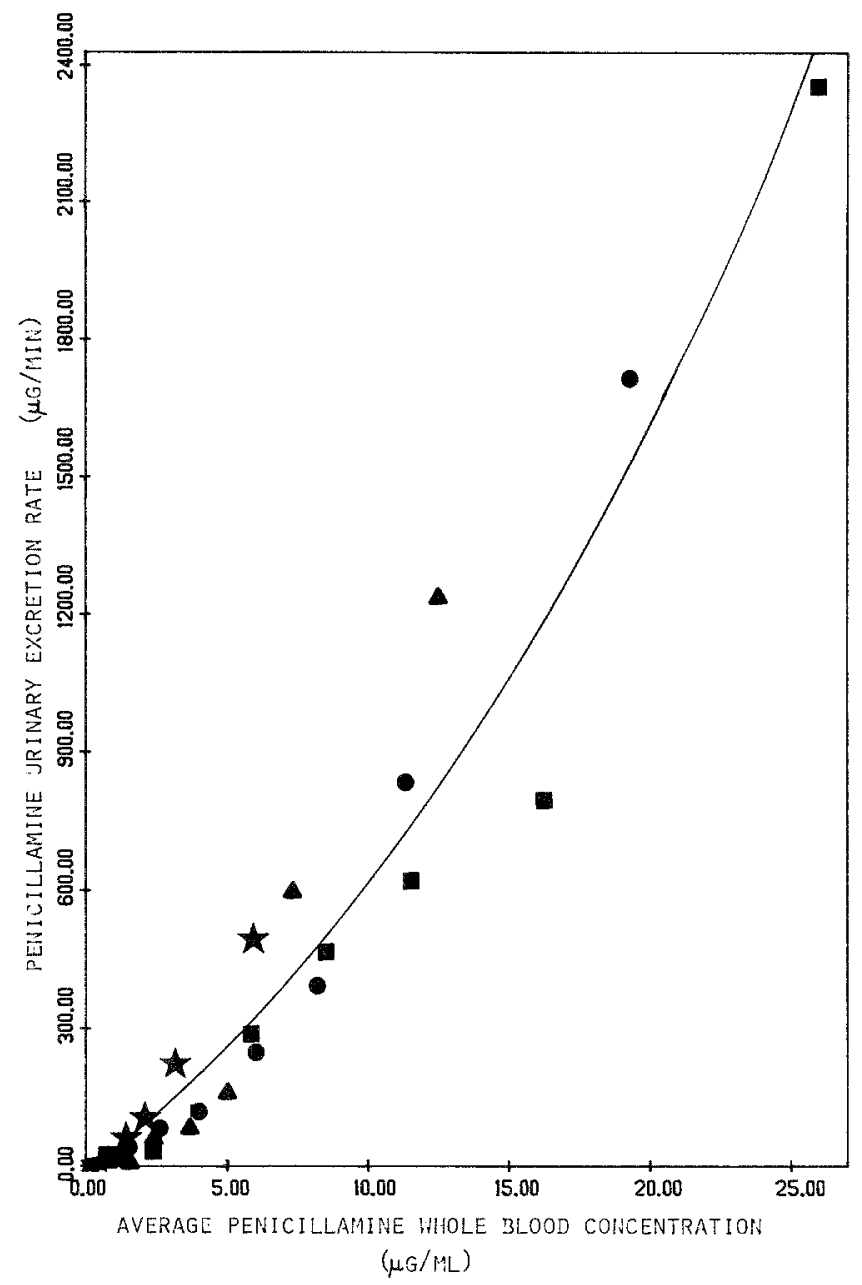

Fig. 3. Penicillamine urinary excretion rate in a female mongrel dog vs, the average whole blood penicillamine concentration at the midpoint of the urine collection interval for the four i.v. bolus doses of penicillamine. Squares, $14.3 \mathrm{mg} / \mathrm{kg}$; circles, $10.7 \mathrm{mg} / \mathrm{kg}$; triangles, $7.1 \mathrm{mg} / \mathrm{kg}$; stars, $3.6 \mathrm{mg} / \mathrm{kg}$.

blood. These results demonstrate that the "apparent" renal clearance of penicillamine was increased by the higher blood levels of penicillamine. These concentration dependent changes observed in the renal clearance of penicillamine for each i.v. bolus dose may be the result of nonlinear plasma protein binding for penicillamine. 


\section{Oral Administration}

The whole blood levels of penicillamine resulting from the administration of four single oral doses of penicillamine are shown in Fig. 4. Two of the doses, both administered as oral solutions, gave a single peak blood level curve, the typical profile for oral administration. However, the other two doses, administered as an oral solution and as a capsule solid dosage form, displayed atypical double blood level patterns. The blood level profile resulting from the administration of the capsule dosage form is highly

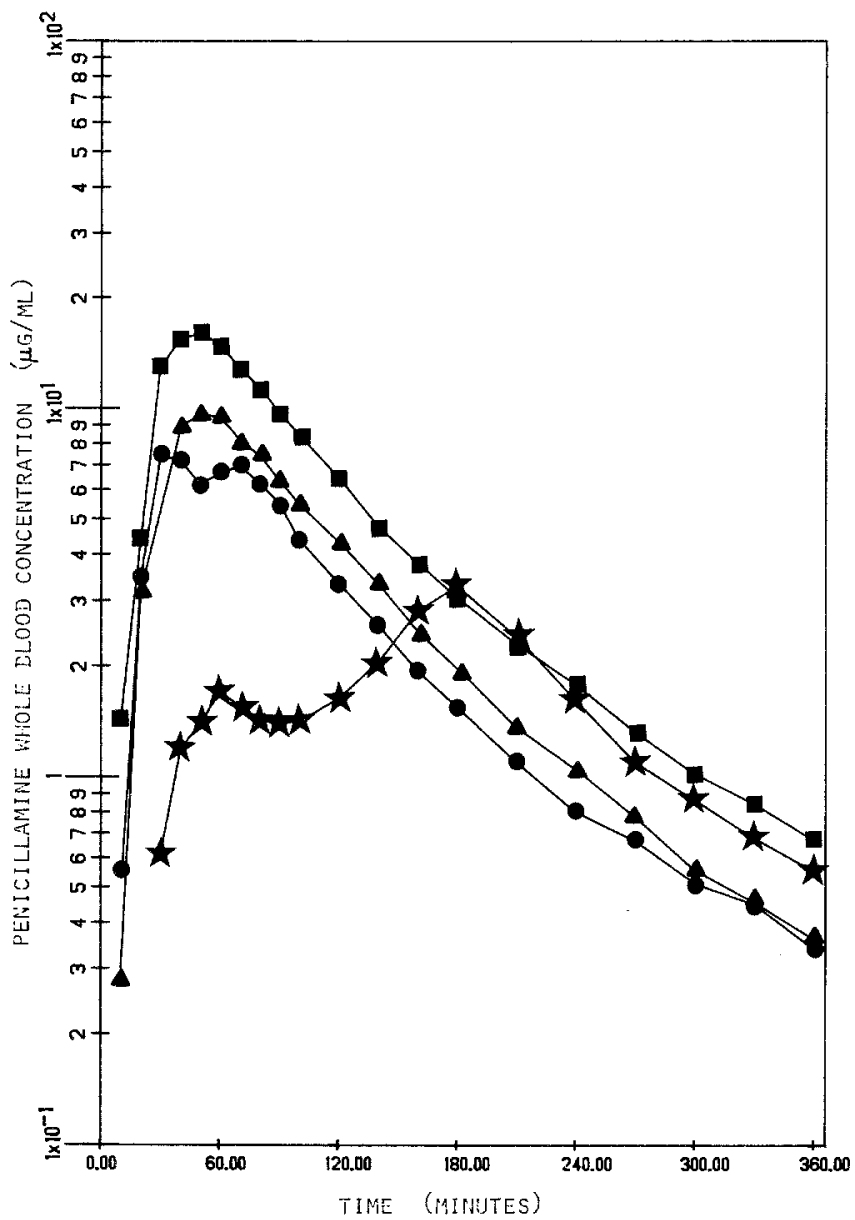

Fig. 4. Penicillamine whole blood concentration vs. time for four oral doses of penicillamine in a female mongrel dog. Squares, $14.3 \mathrm{mg} / \mathrm{kg}$ (solution); circles, $10.7 \mathrm{mg} / \mathrm{kg}$ (solution); triangles, $10.7 \mathrm{mg} / \mathrm{kg}$ (solution); stars, $9.9 \mathrm{mg} / \mathrm{kg}$ (capsules). 
irregular, showing a marked double peak, a significant shift in the relative time course, and a significant reduction in the bioavailability of the capsule dosage form relative to the doses administered as oral solutions.

Comparisons of the area under the curves (AUC) for the oral doses and i.v. bolus doses were done in order to determine the bioavailability. The AUC data and calculated bioavailability factor are shown in Table II. The bioavailability factor reported for the oral solutions is higher than that reported previously (13), but the bioavailability factor reported for the solid dosage form is approximately the same as the previous report.

\section{Intravenous Infusions}

The steady state whole blood, plasma, and packed cell levels of penicillamine achieved during six constant rate penicillamine infusions are listed in Table III. The steady state plasma concentration is plotted vs. infusion rate in Fig. 5. The total body clearance of penicillamine was calculated for each infusion using the steady state plasma and whole blood concentrations, the respective infusion rates, and Eq. (1):

$$
C L=\frac{k_{0}}{C_{s s}}
$$

where $C L$ is the total body clearance, $k_{0}$ is the infusion rate, and $C_{s s}$ is the blood component steady state concentration. The calculated plasma and whole blood total body clearances for the six infusions are shown in Table III.

Table II. Calculation of $\mathrm{FF}^{* a}$ from the Oral and I.V. Dog Experiments for Penicillamine

\begin{tabular}{ccccccc}
\hline $\begin{array}{c}\text { Dose } \\
(\mathrm{mg} / \mathrm{kg})\end{array}$ & $\begin{array}{c}\text { Oral } \\
\text { dose } \\
(\mathrm{mg})\end{array}$ & $\begin{array}{c}\text { Oral } \\
\text { dosage } \\
\text { form }\end{array}$ & $\begin{array}{c}\mathrm{AUC} \\
(\mu \mathrm{g} / \mathrm{ml} / \mathrm{min})^{c}\end{array}$ & $\begin{array}{c}\text { i.v. } \\
\text { dose } \\
(\mathrm{mg})\end{array}$ & $\begin{array}{c}\mathrm{AUC}_{\text {i.v. }}^{0-\infty} \\
(\mu \mathrm{g} / \mathrm{ml} / \mathrm{min})^{c}\end{array}$ & $\mathrm{FF}^{*}$ \\
\hline 14.3 & 370 & soln. & 1800 & 315 & 1600 & 0.96 \\
10.7 & 287 & soln. & 1110 & 245 & 1160 & 0.82 \\
10.7 & 300 & soln. & 921 & 245 & 1160 & 0.65 \\
9.92 & 250 & caps. & 608 & $245^{d}$ & 1160 & 0.51 \\
\hline
\end{tabular}

${ }^{a} \mathrm{FF}^{*}$, the bioavailability factor, is the fraction of the dose that ultimately reaches the circulation. It is the factor used to account for losses due to incomplete absorption and or first pass effects where:

$$
\mathrm{FF}^{*}=\frac{\mathrm{AUC}_{\mathrm{po}}^{0-\infty} \times \mathrm{D}_{\mathrm{i} . \mathrm{v}}}{\mathrm{AUC}_{\mathrm{i} . \mathrm{v} .}^{0-\infty} \times \mathrm{D}_{\mathrm{po}}}
$$

${ }^{b}$ The dose was administered as a solution of penicillamine $(50 \mathrm{mg} / \mathrm{ml}$; see text) or as $125 \mathrm{mg}$ capsules.

${ }^{c}$ The AUC is the area under the whole blood concentration-time curve from zero to infinity.

${ }^{d}$ This dose was actually administered as a $10.7 \mathrm{mg} / \mathrm{kg}$ dose i.v. 
Table III. Steady State Blood Levels of Penicillamine Achieved During Four Hour Constant Rate Intravenous Infusions of Penicillamine in a Female Mongrel Dog

\begin{tabular}{|c|c|c|c|c|c|}
\hline \multirow{2}{*}{$\begin{array}{l}\text { Infusion } \\
\text { rate } \\
(\mu \mathrm{g} / \mathrm{min})\end{array}$} & \multicolumn{3}{|c|}{$\begin{array}{c}\text { Steady state levels }{ }^{a} \\
(\mu \mathrm{g} / \mathrm{ml})\end{array}$} & \multicolumn{2}{|c|}{$\begin{array}{c}\text { Clearance }^{b} \\
(\mathrm{ml} / \mathrm{min})\end{array}$} \\
\hline & $\begin{array}{l}\text { Whole } \\
\text { blood }\end{array}$ & Plasma & $\begin{array}{l}\text { Packed } \\
\text { cells }\end{array}$ & $\begin{array}{l}\text { Whole } \\
\text { blood }\end{array}$ & Plasma \\
\hline 209 & $\begin{array}{c}0.667 \\
(0.022)^{\mathrm{c}}\end{array}$ & $\begin{array}{c}0.821 \\
(0.041)\end{array}$ & $\begin{array}{c}0.294 \\
(0.049)\end{array}$ & 313 & 255 \\
\hline 412 & $\begin{array}{c}1.70 \\
(0.040)\end{array}$ & $\begin{array}{l}2.01 \\
(0.071)\end{array}$ & $\begin{array}{c}0.814 \\
(0.008)\end{array}$ & 243 & 205 \\
\hline 824 & $\begin{array}{l}3.93 \\
(0.063)\end{array}$ & $\begin{array}{l}5.26 \\
(0.26)\end{array}$ & $\begin{array}{c}2.29 \\
(0.21)\end{array}$ & 210 & 157 \\
\hline 1270 & $\begin{array}{c}6.53 \\
(0.26)\end{array}$ & $\begin{array}{c}9.74 \\
(0.36)\end{array}$ & $\begin{array}{c}3.85 \\
(0.26)\end{array}$ & 194 & 130 \\
\hline 1680 & $\begin{array}{l}11.2 \\
(0.30)\end{array}$ & $\begin{array}{l}15.1 \\
(0.76)\end{array}$ & $\begin{array}{c}6.28 \\
(0.75)\end{array}$ & 150 & 111 \\
\hline 2130 & $\begin{array}{l}14.5 \\
(0.80)\end{array}$ & $\begin{array}{l}19.4 \\
(0.21)\end{array}$ & $\begin{array}{c}8.64 \\
(0.22)\end{array}$ & 147 & 110 \\
\hline
\end{tabular}

${ }^{a}$ The average of three observations made during the fourth hour of the intravenous infusion.

${ }^{b}$ The total body clearance calculated from the ratio of the infusion rate over the steady state concentration.

${ }^{c}$ The standard deviations of the observed data points.

From a determination of the amount of penicillamine excreted in the urine over an accurately timed interval during the final hour of each infusion, the urinary excretion rate of penicillamine at steady state was determined. The observed urine excretion rate was divided by the respective steady state whole blood and plasma concentrations to calculate a whole blood or plasma renal clearance of penicillamine, as shown in Eq. (2):

$$
C L_{r}=\frac{d A_{e} / d t}{C_{s s}}
$$

where $C L_{r}$ is the renal clearance, and $d A_{e} / d t$ is the urinary excretion rate at steady state. At steady state, the rate of input must equal the rate of elimination of the drug. Therefore, the relationship expressed in Eq. (3) exists:

$$
k_{0}=d A_{e} / d t+d A_{m} / d t
$$

where $d A_{m} / d t$ is the nonrenal elimination rate at steady state. Because the infusion rates of penicillamine that were used are accurately known, and the urinary excretion rates were directly measured, the nonrenal 


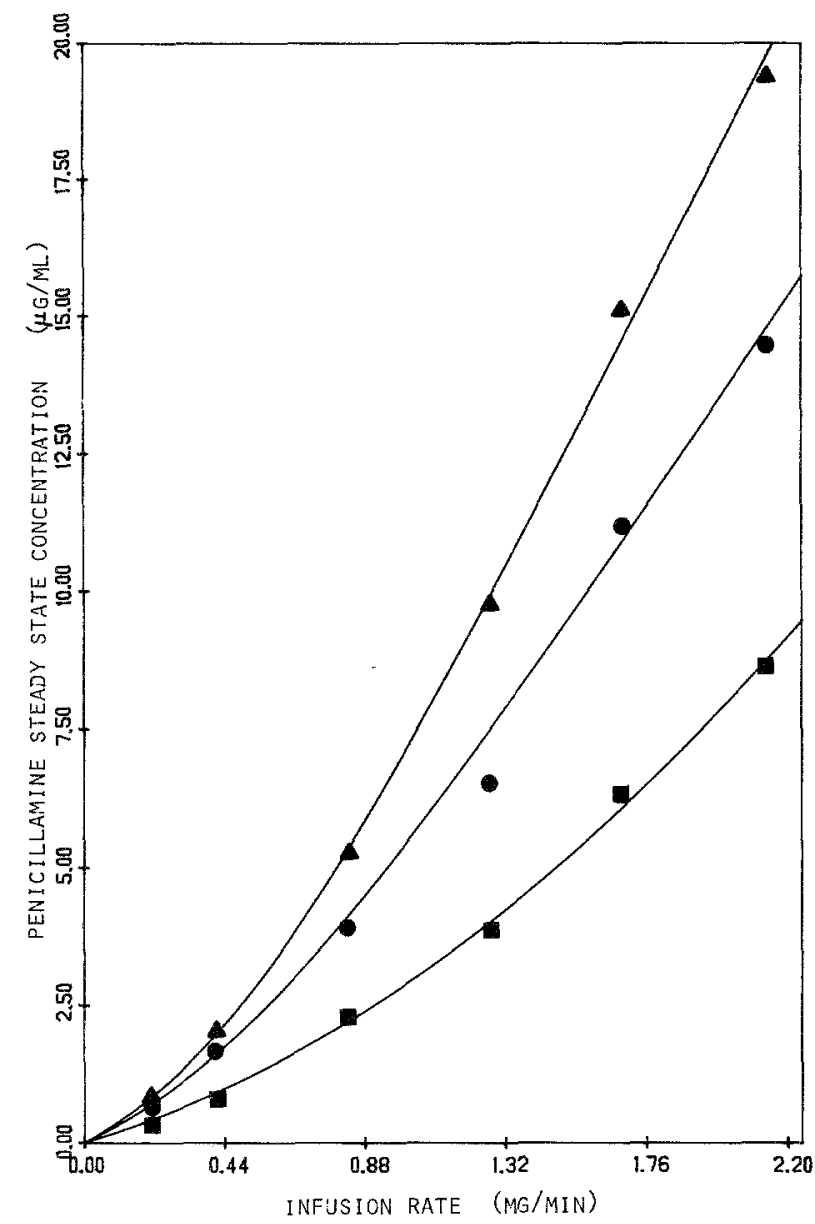

Fig. 5. Steady state penicillamine concentrations of plasma, whole blood, and packed cells vs. the penicillamine intravenous infusion rate in a female mongrel dog. Triangles, plasma levels; circles, whole blood levels; squares, packed cell levels.

elimination rates of penicillamine in the dog can be calculated by solving Eq. (3) for $d A_{m} / d t$. These rates are plotted vs. steady state concentration in Fig. 6.

The observed urine elimination rates for five of the six intravenous infusions and the calculated renal and nonrenal clearances of penicillamine are listed in Table IV. The urinary elimination rate data for the $1270 \mu \mathrm{g} / \mathrm{ml}$ infusion were omitted because of an error that occurred during the collection of the urine specimen. 


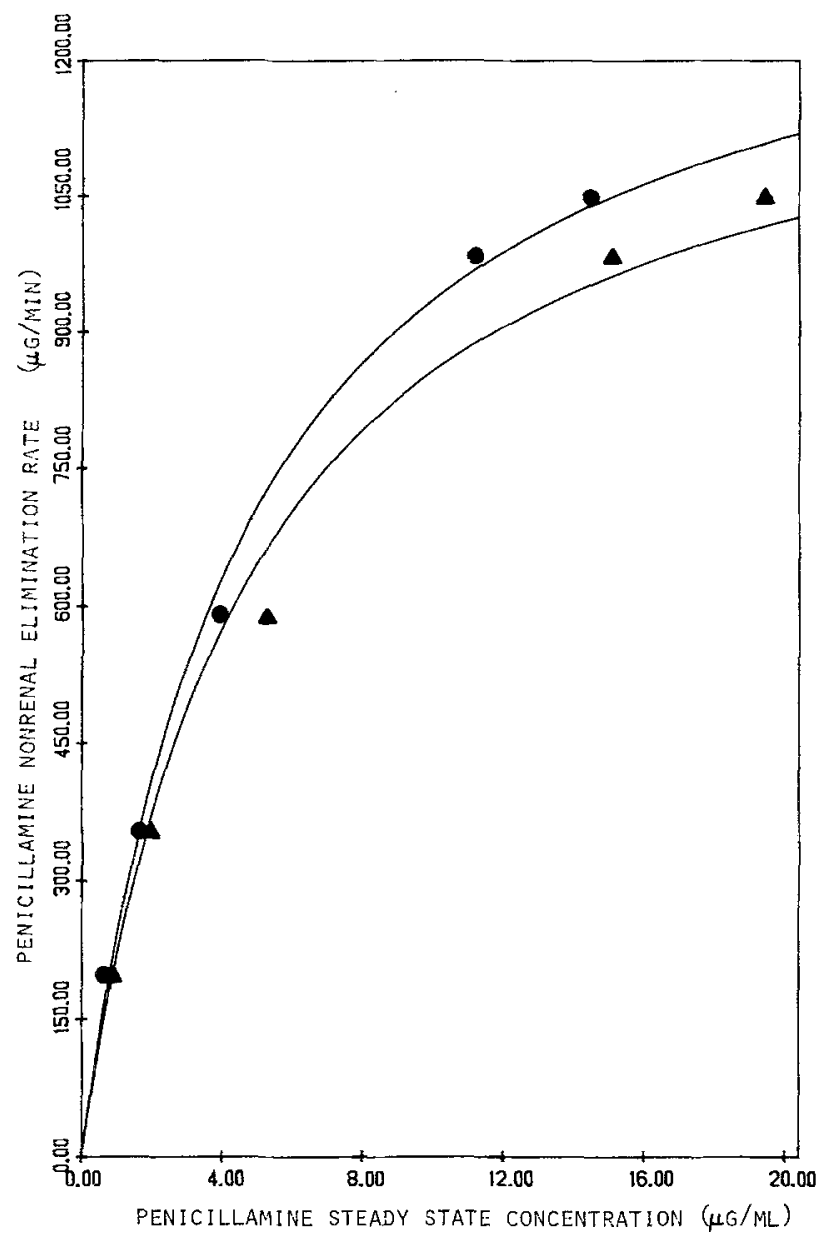

Fig. 6. The nonrenal elimination rate of penicillamine vs. the steady state concentrations of penicillamine in plasma and whole blood of a female mongrel dog. Circles, whole blood; triangles, plasma.

\section{DISCUSSION}

The pharmacokinetic parameters determined for D-penicillamine in the female mongrel dog exhibited nonlinear relationships relative to the doses. For the i.v. bolus studies, as the dose was increased over a fivefold range, there was a reduction in the total body clearance and an increase in the estimated half-life. The doses of penicillamine were administered to the dog on a $\mathrm{mg} / \mathrm{kg}$ basis such that the doses were equivalent to administer- 
Table IV. Urinary Excretion Rates ${ }^{a}$ and Renal and Nonrenal Clearances of Penicillamine after the Attainment of Steady State During Four Hour Constant Intravenous Infusions in a Female Mongrel Dog

\begin{tabular}{|c|c|c|c|c|c|}
\hline \multirow{2}{*}{$\begin{array}{l}\text { Infusion } \\
\text { rate } \\
(\mu \mathrm{g} / \mathrm{min})\end{array}$} & \multirow{2}{*}{$\begin{array}{l}\text { Urine } \\
\text { Excretion }^{b} \\
\text { rate } \\
(\mu \mathrm{g} / \mathrm{min})\end{array}$} & \multicolumn{2}{|c|}{$\begin{array}{l}\text { Renal clearance }^{c} \\
(\mathrm{ml} / \mathrm{min})\end{array}$} & \multicolumn{2}{|c|}{$\begin{array}{l}\text { Nonrenal clearance } \\
(\mathrm{ml} / \mathrm{min})\end{array}$} \\
\hline & & $\begin{array}{l}\text { Whole } \\
\text { blood }\end{array}$ & Plasma & $\begin{array}{l}\text { Whole } \\
\text { blood }\end{array}$ & Plasma \\
\hline 209 & 10.9 & 16.3 & 13.3 & 297 & 242 \\
\hline 412 & 57.8 & 34.0 & 28.8 & 209 & 176 \\
\hline 824 & 234 & 59.5 & 44.4 & 150 & 113 \\
\hline 1270 & $-^{e}$ & - & - & - & - \\
\hline 1680 & 698 & 62.3 & 46.2 & 87.7 & 64.8 \\
\hline 2130 & 1090 & 74.9 & 56.0 & 72.1 & 54.0 \\
\hline
\end{tabular}

${ }^{a}$ The urine was collected over the last hour of the intravenous infusion when the blood levels of penicillamine were at steady state.

${ }^{b}$ The urinary excretion rate is calculated from the amount of unchanged penicillamine excreted in the urine during the last hour of the intravenous infusion divided by the length of the urine collection period.

${ }^{c}$ The renal clearance was calculated by dividing urinary excretion rate by the steady state blood level.

${ }^{d}$ The nonrenal clearance was calculated from the difference between the total body clearance (see Table II) and the calculated renal clearance for a given infusion rate.

${ }^{e}$ These data were omitted due to an error in the collection of the urine specimen.

ing $250,500,750$, and $1000 \mathrm{mg}$ of D-penicillamine to a $70 \mathrm{~kg}$ man, the dosage range used clinically.

As in the case of the i.v. bolus results, the infusion data were nonlinear, also showing a decrease in the total body clearance as the infusion rate increased. For the infusion data presented in Table III, the largest change in the total body clearance of penicillamine occurred at the lowest two infusion rates. The observed decrease in the clearance became less the more the infusion rate was increased. A similar conclusion is drawn from Table I for the i.v. bolus data. In these data, the largest change in the clearance occurred between the two lowest doses and the smallest change between the highest doses. These results suggest that there are parallel nonlinear and linear elimination processes for penicillamine in this female mongrel dog. As the dosage rate was increased, the nonlinear elimination process became saturated, and the overall elimination kinetics of penicillamine approached linearity.

The relationship between the infusion rate and the steady state concentration can therefore be described by Eq. (4), which consists of linear 
and nonlinear components:

$$
k_{0}=C_{s s}\left[P(1)+\frac{P(2)}{P(3)+C_{s s}}\right]
$$

where $P(1)$ has units of clearance, volume/time, $P(2)$ has units of mass/time, and $P(3)$ has units of mass/volume. However, Eq. (4) is written expressing the infusion rate as a function of the steady state concentration. An explicit solution for the steady state concentration as a function of the infusion rate does not exist, but Eq. (4) can be rearranged into a quadratic function as shown in Eq. (5):

$$
P(1) *\left(C_{s s}\right)^{2}+\left(P(1) * P(3)+P(2)-k_{0}\right) * C_{s s}-k_{0} * P(3)=0
$$

Therefore, the steady state concentration can be expressed as the positive quadratic root of Eq. (5), as shown in Eq. (6):

$$
C_{s s}=\frac{-b+S Q R\left(b^{2}-4 a c\right)}{2 a}
$$

where $a=P(1), b=P(1) * P(3)+P(2)-k_{0}$, and $c=-k_{0} * P(3)$.

Initial estimates of the parameters $P(1), P(2)$, and $P(3)$ were obtained graphically. A linear regression of the data for the three highest infusion rates gave the initial estimates for $P(1)$, the slope from the regression, and $P(2)$, the intercept from the linear regression. An initial estimate of $P(3)$ was obtained by solving Eq. (4) for $P(3)$ and using the observed infusion rate steady state concentration data and the initial estimates of the other parameters to give an average initial estimate of $P(2)$.

The plasma and whole blood concentration data were fitted to Eq. (5), using the digital computer program NONLIN (25) and the initial estimates of the parameters $P(1), P(2)$, and $P(3)$. Summaries of the results of the NONLIN fits for the plasma and whole blood data are shown in Table V.

The exact interpretation of these parameters, however, is not clear, as the parameters of Eq. (4) are pooled parameters resulting from the overall elimination process for penicillamine in this female mongrel dog. Both the renal and nonrenal components of clearance were observed to be nonlinear, as shown in Table IV. Thus the linear and nonlinear components of penicillamine's elimination as theorized by Eq. (4) cannot be accurately ascribed to specific physiological functions by a simple assessment of the observed data. 
Table V. Summary of the Results of the NONLIN Fit of the Intravenous Infusion Rates of Penicillamine and the Steady State Whole Blood and Plasma Concentration Levels

\begin{tabular}{lccccc}
\hline & & \multicolumn{3}{c}{ Parameters $^{a}$} \\
\cline { 3 - 5 } $\begin{array}{c}\text { Steady state } \\
\text { level of }\end{array}$ & $\begin{array}{c}\text { Number of } \\
\text { observations }\end{array}$ & $\begin{array}{c}P(1) \\
(\mathrm{ml} / \mathrm{min})\end{array}$ & $\begin{array}{c}P(2) \\
(\mathrm{mg} / \mathrm{min})\end{array}$ & $\begin{array}{c}P(3) \\
(\mu \mathrm{g} / \mathrm{ml})\end{array}$ & $R^{2 b}$ \\
\hline Plasma & 18 & 82.6 & 0.565 & 2.49 & 0.999 \\
Whole blood & 15 & $(4.2)$ & $(0.093)$ & $(0.71)$ & 0.998 \\
& & 110 & 0.594 & 2.47 & $0.964)$ \\
& & $(7.3)$ & $(0.132)$ & $(0.75)$ & \\
\hline
\end{tabular}

${ }^{a}$ The parameters of Eq. (4) used to express the relationship between the infusion rate and the steady state concentration in plasma or whole blood.

${ }^{b}$ The coefficient of determination for the NONLIN fits.

The renal excretion rates observed in both the i.v. bolus and the infusion studies were nonlinear; the observed nonlinearity may be the result of nonlinear penicillamine plasma protein binding, as has been demonstrated for other compounds $(26,27)$. However, due to rapid degradation of penicillamine in the presence of biological media such as albumin solutions or plasma (19), the protein binding of penicillamine cannot be easily and accurately determined using conventional methods.

The relationship of the nonrenal elimination rate versus the steady state concentration is shown in Fig. 6. From these data it is apparent that the nonrenal elimination kinetics of penicillamine in this female mongrel dog can be described by Michaelis-Menten kinetics. As the steady state or infusion rate was increased, there was a less than proportional increase in the nonrenal elimination rate. As the larger infusion rates were employed, the nonrenal elimination process approached a saturation level.

In conclusion, the data presented for the i.v. bolus and infusion studies of penicillamine in this female mongrel dog are consistent with a model for penicillamine involving metabolism occurring according to one probably pooled Michaelis-Menten kinetic process and renal excretion probably occurring according to nonlinear saturable protein binding. More studies are necessary to accurately characterize the pharmacokinetics of penicillamine following oral administration in the female mongrel dog. But the results presented in this paper give an indication of some of the general characteristics of penicillamine upon oral administration.

The presence of a double peak following oral administration of penicillamine in the female mongrel dog presents an unusual pharmacokinetic profile for the oral administration of a drug. However, similar double peaks have also been observed following oral administration of penicillamine in man (29) as well as for other drugs (30-32). 


\section{REFERENCES}

1. J. M. Walshe. Penicillamine, a new oral therapy for Wilson's disease. Am. J. Med. 21:487-495 (1956).

2. E. P. Abrams, E. Chain, W. Baker, and R. Robinson. Penicillamine, a characteristic degradation product of penicillin. Nature 151:107 (1943).

3. Multicenter Trial Group. Controlled trial of $\mathrm{D}-(-)$-penicillamine in severe rheumatoid arthritis. Lancet 1:275 (1973).

4. Y. Shiokawa, Y. Horiuchi, M. Honma, T. Kageyma, T. Okada, and T. Azuman. Clinical observation of $D$-penicillamine by multicentre double-blind comparative study in chronic rheumatoid arthritis. Arthritis Rheum. 20:1464-1472 (1977).

5. R. R. Pal. Colorimetric estimation of Penicillamine. J. Biol. Chem. 234:618-619 (1959).

6. E. Jellum, V. A. Bacon, W. Patton, W. Pereira, Jr., and B. Halpern. Quantitative determination of biologically important thiols and disulfides by gas-liquid chromatography. Anal. Biochem. 31:339-347(1969).

7. E. S. K. Assem. Assay of penicillamine in blood and urine. Curr. Med. Res. Opin. 2:568-572 (1974).

8. E. S. K. Assem and M. R. Vickers. The immunological assay of penicillamine. Postgrad. Med. J. 50(S2):10-14 (1974).

9. F. Planas-Bohne. Pharmacokinetics of ${ }^{14} \mathrm{C}$-D-penicillamine. Arzneim.-Forsch. 22:14261433 (1972).

10. E. Polig and F. Planas-Bohne. Compartmental study on the pharmacokinetics of Dpenicillamine. Biophysik 10:321-336 (1973).

11. A. Ruiz-Torres. On the pharmacokinetics and metabolism of $D$ - and L-penicillamine 1st communication: blood levels, transport. Arzneim.-Forsch. 24:914-917 (1974).

12. A. Ruiz-Torres. On the pharmacokinetics and metabolism of D- and L-penicillamine 2nd communication: distribution of $\mathrm{D}$ - and L-penicillamine in the rat organism after oral administration. Arzneim.-Forsch. 24:1043-1046 (1974).

13. V. A. Ruiz-Torres and I. Kürten. On the pharmacokinetics and metabolism of $D$ - and L-penicillamine 3rd communication: adsorption, excretion, and metabolism. Arzneim.Forsch. 24:1258-1261 (1974).

14. K. Patzschke and L. A. Wegner. Pharmacokinetic studies after the application of ${ }^{14} \mathrm{C}-\mathrm{D}-$ penicillamine to rats. Arzneim.-Forsch. 27:1152-1158 (1977).

15. P. Wei and A. Sass-Kortsak. Urinary excretion and renal clearance of D-penicillamine in humans and the dog. Gastroenterology 58:288 (1970).

16. K. Gibbs and J. M. Walshe. Studies with ${ }^{35} \mathrm{~S}$-labeled DL-penicillamine in patients with Wilson's disease. Q. J. Med. 40:275-287 (1971).

17. K. Patzschke, L. Wegner, H. Kaller, and F. A. Horster. Pharmakokinetische untersuchungen nach oraler Applikation von radioaktiv markiertem D-penicillamin an probanden. Z. Rheumatol. 36:96-105 (1977).

18. D. Perrett, W. Sheddon, and A. D. Stephens. Studies on D-penicillamine metabolism in cystinuria and rheumatoid arthritis: Isolation of S-methyl-penicillamine. Biochem. Pharmacol. 25:259-264 (1976).

19. R. F. Bergstrom, D. R. Kay, and J. G. Wagner. The in-vitro loss of penicillamine in plasma, albumin solutions, and whole blood: Implications for pharmacokinetic studies of penicillamine. Life Sci. 27:189-198 (1980).

20. R. Saetre and D. L. Rabinstein. Determination of penicillamine in blood and urine by high performance liquid chromatography. Anal. Chem. 50:276-280 (1978).

21. A. S. Russell, R. Saetre, P. Davis, and D. L. Rabenstein. A rapid, sensitive technique to assay penicillamine levels in blood and urine. J. Rheumatol. 6:15-19 (1979).

22. R. F. Bergstrom, D. R. Kay, and J. G. Wagner. High performance liquid chromatographic determination of penicillamine in whole blood, plasma, and urine. J. Chromatogr. (in press).

23. B. J. Bowers, Jr., P. Vermeit, and J. Wemer. Stability of D-penicillamine in aqueous solution. Pharm. Weekblad. 112:121-129 (1977). 
24. A. J. Sedman and J. G. Wagner. CSTRIP, a fortran IV computer program for obtaining initial polyexponential parameter estimates. J. Pharm. Sci. 65:1006-1010 (1976).

25. C. M. Metzler. Biostatistical Technical Report 7292/69/7292/005. The Upjohn Company, Kalamazoo, Mich. November 25, 1969.

26. R. Runkel, E. Forchielli, H. Sevelius, M. Chaplin, and E. Segre. Nonlinear plasma level response to high doses of naproxen. Clin. Pharmacol. Ther. 15:261-266 (1974).

27. G. Levy. Effect of plasma protein binding on renal clearances of drugs. J. Pharm. Sci. 69:482-483 (1980).

28. J. D. Robinson, B. A. Morris, G. W. Aherne, and V. Marks. Pharmacokinetics of a single dose of phenytoin in man measured by radioimmunoassay. Br. J. Clin. Pharmacol. 2:345-349 (1975).

29. R. F. Bergstrom, D. R. Kay, T. M. Harkcom and J. G. Wagner. Penicillamine kinetics in normal subjects. Clin. Pharmacol. Ther. 30:404-413 (1981).

30. G. Bodemar, B. Norlander, L. Fransson, and A. Walan. The influence of a meal and antacids on cimetidine absorption in patients with peptic ulcer disease. Scand. J. Gastroenterol. 12 (S45): 12 (1977).

31. W. A. Colburn, P. C. Hirom, R. J. Parker, and P. Milburn. A pharmacokinetic model for enterohepatic recirculation in the rat: Phenolphthalein, a model drug. Drug. Metab. Dispos. 7:100-102 (1979).

32. A. Grahnén, C. von Bahr, B. Lindström, and A. Rosén. Bioavailability and pharmacokinetics of cimetidine. Eur. J. Clin. Pharmacol. 16:335-340 (1979). 